\title{
Effective nitrogen preservation during urine collection from Holstein heifers fed diets with high or low protein content
}

\author{
K. F. Knowlton, ${ }^{1}$ M. L. McGilliard, Z. Zhao, K. G. Hall, W. Mims, and M. D. Hanigan \\ Department of Dairy Science, Virginia Polytechnic Institute and State University, Blacksburg 24061
}

\begin{abstract}
Six Holstein heifers (body weight $=535-625 \mathrm{~kg}$ ) fed a total mixed ration containing either high protein $(13.4 \%)$ or low protein $(9.0 \%)$ were used to evaluate the effect of 3 urine collection methods (chilled, acidified before collection, or acidified after $6 \mathrm{~h}$ of collection) on urinary $\mathrm{N}$ preservation. In a 2-period crossover design, 16-d diet adjustment stages preceded five 24-h collections. Urinary catheters were inserted $1 \mathrm{~d}$ before the collection periods. Urine collection tubes were configured to split urine to 3 collection containers: 1 acidified with $6 \mathrm{~N} \mathrm{HCl}$ before collection at a rate calculated to reduce $\mathrm{pH}$ to below 2,1 acidified every $6 \mathrm{~h}$ during collection to $\mathrm{pH}$ below 2, and 1 located in a large cooler of ice. Collection method did not affect urinary concentration of $\mathrm{N}$ or urine urea- $\mathrm{N}(9.2 \pm 0.9 \mathrm{~g} / \mathrm{L}$ and 6.58 $\pm 0.9 \mathrm{~g} / \mathrm{L}$, respectively) or urinary excretion of $\mathrm{N}$ or urea-N $(82 \pm 3.8 \mathrm{~g} / \mathrm{d}$ and $59.5 \pm 3.8 \mathrm{~g} / \mathrm{d}$, respectively). These 3 collection methods are equally effective in preserving $\mathrm{N}$ during urine collection, but the "chilled immediately" approach may be useful for studies focused on ammonia emission. Urinary and fecal $\mathrm{N}$ excretion were significantly different across collection days; fecal $\mathrm{N}$ was more highly variable than urinary $\mathrm{N}$. Intake and apparent $\mathrm{N}$ digestibility decreased during the collection week, and excretion of urinary and fecal $\mathrm{N}$ increased, particularly on d 5. (Stable rectal temperatures suggested no urinary infections.) Improvements in total collection methodology will support continued progress in the understanding of livestock $\mathrm{N}$ utilization and post-excretion changes in manure $\mathrm{N}$.
\end{abstract}

Key words: urine nitrogen, storage, dietary protein, heifer

\section{INTRODUCTION}

Various preservation methods have been used to minimize urinary and fecal $\mathrm{N}$ volatilization during total collection, with most efforts focused on preserving urinary

Received July 29, 2009.

Accepted September 20, 2009.

${ }^{1}$ Corresponding author: knowlton@vt.edu
N. Nitrogen may be lost during sample collection and storage as a result of urea decomposition and ammonia volatilization. These compounds are a minor part of fecal N (Misselbrook et al., 2005; Sato and Nakajima, 2005), but account for most of the urinary N (Burge et al., 1993; Marini and Van Amburgh, 2005; Colmenero and Broderick, 2006).

In the early 20th century, sulfuric acid was identified as effective in preserving ammonia $\mathrm{N}$ in urine of steers (Cochrane, 1915); the author of this work concluded that "figures for total ammonium $\mathrm{N}$ are worthless unless special precautions are taken to overcome the rapid ammoniacal decomposition." Since the time of that observation, several acids (sulfuric, hydrochloric, boric, phosphoric) have been used with success. López et al. (1998) demonstrated that, as long as the acidified urine had similar final $\mathrm{pH}$, sulfuric or hydrochloric acid was equally effective in retaining $\mathrm{N}$ in sheep and goat urine. Ferraz et al. (2006) demonstrated that acidification with hydrochloric acid before or after 24-h human urine collection was effective in preserving urinary oxalate, calcium, magnesium, citrate, creatinine, and uric acid.

For unacidified urine samples, temperature during storage is an important consideration. Watson and Duerden (1977) observed that refrigeration at $4^{\circ} \mathrm{C}$ was effective in preventing bacterial growth in human urine for up to $72 \mathrm{~h}$. Similarly, Porter and Brodie (1969) observed less bacterial growth in samples chilled during shipping $\left(9-15^{\circ} \mathrm{C}, 2-3 \mathrm{~d}\right.$ shipping time) than in urine samples shipped without preservation. Samples chilled during shipping yielded similar results to those acidified with boric acid if transit time was $6 \mathrm{~h}$ or less, but if chilled samples were delayed in transit, bacterial growth was greater than in acidified samples. Even acidified samples may need to be chilled; human urine samples preserved with boric acid and stored overnight had altered culture results compared with acidified samples analyzed on the day of collection (Gillespie et al., 1999).

Dietary $\mathrm{N}$ content can alter the $\mathrm{N}$ profile of urine samples, and high-protein diets may challenge preservation methods by increasing urinary $\mathrm{N}$ content, especially the concentration of urine urea N. When Holstein heifers were fed diets with increasing dietary 
$\mathrm{N}$ content $(1.5-3.4 \%)$, the urea $\mathrm{N}$ content of urine increased from 18 to $79 \%$ of total urinary N (Marini and Van Amburgh, 2003). Similarly, in lactating cows almost all of the increase in $\mathrm{N}$ excretion with increasing dietary RDP content was in the urine, and urine urea $\mathrm{N}$ increased from 68 to $81 \%$ of urinary N (Reynal and Broderick, 2005).

Ammonia emissions from manure have become a significant air quality concern because ammonia catalyzes the formation of small particles, leading to the formation of haze. These small particles also have negative human health implications (NRC, 2003). To better understand the effect of diet on ammonia emissions, it is advantageous to collect urine and feces for use in emissions studies. To be applicable, these samples need to remain in a natural state. Given that acidification of the samples traps liberated ammonia in solution, it is not possible to study ammonia emission rates when the samples have been acidified. Therefore, alternative collection methods that maintain the biological activity of the samples are needed.

Duration of collection of feces necessary for accurate and repeatable measurement of digestibility was the subject of numerous publications in the early part of the 20th century. In general, collection periods of at least $7 \mathrm{~d}$ were preferred, and collection periods of up to $24 \mathrm{~d}$ were used in some studies. The focus of these reports was feces collection; when urinary catheterization is used, the question of duration of collection period is worth revisiting because of the risk of urinary tract infections (Biertuempfel et al., 1981; Warren, 2001).

The objective of this study was to compare the effects of 3 collection methods on $\mathrm{N}$ preservation of urine samples from Holstein heifers fed diets that differed in protein content. In addition, the effect of duration of collection period on variability of $\mathrm{N}$ excretion data was evaluated.

\section{MATERIALS AND METHODS}

\section{Animals and Diets}

All animal work was approved by the Virginia Tech Animal Care and Use Committee. Six pregnant Holstein heifers $(170 \pm 8.7 \mathrm{~d}$ in gestation at the start of study; BW 535-625 kg) were fed 2 dietary treatments (Table 1) in a crossover design with two 21-d periods. The treatments were a high-protein (HP) diet (13.4\%) and a low-protein (LP) diet (9.0\%). Diets with HP supplied $121 \%$ of NRC-required protein and LP diets supplied $70 \%$ of the required protein (NRC, 2001). Treatment groups were balanced for BW and days pregnant. Heifers were housed in a single group in a freestall barn and fed in Calan doors (American Calan, Northwood, NH)
Table 1. Ingredient and chemical composition of treatment diets ${ }^{1}$ fed to 6 Holstein heifers

\begin{tabular}{lcc}
\hline Item & HP & LP \\
\hline Ingredient, \% of dietary DM & & \\
Corn silage & 31.2 & 31.2 \\
Wheat straw & 12.8 & 12.8 \\
Grass hay & 39.6 & 39.6 \\
Corn grain & 0.0 & 11.6 \\
Soybean meal (48\%) & 14.4 & 2.8 \\
Mineral-vitamin mix & 2.0 & 2.0 \\
Chemical composition & & \\
DM & 60.8 & 60.7 \\
CP & 13.35 & 9.01 \\
NDF & 53.79 & 53.56 \\
ADF & 30.04 & 29.36 \\
Ca & 0.72 & 0.56 \\
P & 0.29 & 0.32 \\
Mg & 0.32 & 0.28 \\
Ash & 7.84 & 6.74 \\
\hline
\end{tabular}

${ }^{1} \mathrm{HP}=$ high protein; $\mathrm{LP}=$ low protein.

${ }^{2}$ Contained $19.1 \% \mathrm{Ca} ; 6.1 \% \mathrm{P} ; 6.4 \% \mathrm{Na} ; 10.1 \% \mathrm{Cl} ; 2.0 \% \mathrm{~K} ; 3.5 \% \mathrm{Mg}$; $2.0 \% \mathrm{~S} ; 31 \mathrm{ppm}$ of Cu; $940 \mathrm{ppm}$ of Zn; $840 \mathrm{ppm}$ of Mn; $31 \mathrm{ppm}$ of Co; $64 \mathrm{ppm}$ of I; $20 \mathrm{ppm}$ of Se; 48,351 IU/kg of vitamin A; 88,889 IU $/ \mathrm{kg}$ of vitamin $\mathrm{D} ; 7.8 \mathrm{mg} / \mathrm{kg}$ of vitamin $\mathrm{E}$.

once daily at $1400 \mathrm{~h}$. Heifers were fed for $10 \%$ refusals and water was available ad libitum. Feed offered and refused was recorded daily and individual ration ingredients of hay, straw, corn silage, and grain mix were sampled weekly throughout the study.

Heifers were handled regularly, trained to the halter, and adapted to the Calan doors for 1 wk before the start of the study. On d 10 of the first period, all heifers were brought to the metabolism barn for a 24-h acclimation period to evaluate response to confinement to the metabolism stalls. Heifers were calm, with little vocalization or restlessness, and were returned to the Calan doors for the remainder of the diet adaptation period.

\section{Sample Collection}

Total collections of urine and feces were conducted in 5-d balance periods following $16 \mathrm{~d}$ of diet adaptation. On d 15 of each period, heifers were fitted with a urinary catheter (22 French, 75 mL; C.R. Bard Inc., Covington, GA) and moved into metabolism stalls for a 24-h adaptation period. Daily feed offered and refused was recorded during the balance periods. Feed refusals were sampled by heifer on each day of each balance period. Rectal temperatures were measured daily at $0600 \mathrm{~h}$.

Every $6 \mathrm{~h}$, feces were removed from behind the heifer and placed in 130-L plastic containers and sealed. Feces were weighed, pooled by day, mixed thoroughly, and subsampled every $24 \mathrm{~h}$. For urine collection and preservation, the urinary catheter was connected to 
Table 2. Statistical model used to analyze all variables ${ }^{1}$

\begin{tabular}{|c|c|c|c|c|}
\hline \multirow[b]{2}{*}{ Source } & \multicolumn{2}{|c|}{ Urine measures } & \multicolumn{2}{|c|}{ All other measures } \\
\hline & df & Error df & df & Error df \\
\hline Treatment & 1 & 10 & 1 & 10 \\
\hline Collection method & 2 & 20 & $\mathrm{NA}^{2}$ & NA \\
\hline Treatment $\times$ collection method & 2 & 20 & NA & NA \\
\hline Collection day & 4 & 40 & 4 & 40 \\
\hline Treatment $\times$ collection day & 4 & 40 & 4 & 40 \\
\hline Collection method $\times$ collection day & 8 & 80 & NA & NA \\
\hline Treatment $\times$ collection method $\times$ collection day & 8 & 80 & NA & NA \\
\hline Total & 179 & & 59 & \\
\hline
\end{tabular}

${ }^{1}$ Error terms were interactions with heifer.

${ }^{2} \mathrm{NA}=$ not applicable.

approximately $2 \mathrm{~m}$ of Tygon tubing (Saint-Gobain Performance Plastics, Akron, $\mathrm{OH}$ ) that ran from the catheter through a leg band to a sterile urine collection bag (C. R. Bard Inc.) fastened to the stall divider. The top of the urine bag was mounted $1 \mathrm{~m}$ from the base of the stall to allow optimum flow (gravity flow) to all 3 collection containers. From the bag, a $10-\mathrm{cm}$ piece of Tygon tubing entered a 3 -way splitter. Tubing attached to the outlets of the splitter entered three $20-\mathrm{L}$ polypropylene collection containers via a $10-\mathrm{mm}$ hole in the screw-on caps (drilled to fit snugly around Tygon tubing). Every $6 \mathrm{~h}$, all urine collection containers were weighed, processed as described below, and replaced with clean collection containers.

For the ice treatment, 20-L collection containers were filled approximately $75 \%$ with water and frozen. At the start of each collection week, containers with ice (1 per heifer) were removed from the freezer, filled to the rim with cold water, and placed in large foam coolers. A second empty collection container was placed in the cooler adjacent to the ice-filled collection container. Tubing carrying urine destined for the ice treatment was coiled through the water at the top of the ice-filled collection container to improve cooling effectiveness. Urine then flowed into the collection container; level of urine in the final container was always lower than level of ice in the cooling container, facilitating gravity flow.

For the "acid-before" treatment, a preliminary experiment was conducted to determine the expected volume of urine excreted by heifers in $6 \mathrm{~h}$ and the quantity of acid needed to reduce $\mathrm{pH}$ to $<2$. Based on the results of that study, $500 \mathrm{~mL}$ of $6 \mathrm{~N} \mathrm{HCl}$ was added to the acid-before collection containers. The final $\mathrm{pH}$ of urine in the acid-before treatment ranged from 0.4 to 1.7. The urine in the "acid-after" collection container for each heifer was acidified at the end of each 6 -h period according to the urine:acid ratio in the acid-before collection container for that same heifer. Every 24 h, urine was pooled by heifer and storage treatment, $\mathrm{pH}$ was measured, and samples were collected and frozen immediately.

\section{Laboratory Analysis}

Feed and feed refusal samples were dried at $60^{\circ} \mathrm{C}$ to a constant weight and ground through a 1-mm screen in a Wiley Mill (Arthur H. Thomas, Philadelphia, PA). Feed ingredients were analyzed in duplicate for NDF and ADF (Van Soest et al., 1991), total Kjeldahl N, ash, Ca, P, and Mg (AOAC, 1984). Refusals, feces, and urine samples were analyzed in duplicate for total Kjeldahl N (AOAC, 1984). Urine samples were analyzed in duplicate for urea plus ammonia-N (reported as urea N; Kaplan, 1965).

\section{Statistical Analysis}

The effects of diets, collection methods (urine measures only), collection days, and their interactions were analyzed using the MIXED procedure of SAS (SAS Institute, 2004) with the model defined in Table 2. A compound symmetry covariance structure for day (subject $=$ heifer $\times$ diet) was used in analyzing all data. Orthogonal contrasts were used to evaluate the linear and quadratic effects of day, and the slice option was applied to interactions to determine significance on each day of collection. Results are reported as least squares means, and differences were declared significant at $P<$ 0.05 . Trends were declared at $P<0.10$.

\section{RESULTS AND DISCUSSION}

\section{Dietary Protein and Utilization of DM and $\mathrm{N}$}

The effects of dietary treatment (HP vs. LP) on DMI, DM digestibility, $\mathrm{N}$ intake, urine output, urinary $\mathrm{N}$, fecal $\mathrm{N}$, total $\mathrm{N}$ excretion, $\mathrm{N}$ digestibility, and $\mathrm{N}$ balance are shown in Table 3. Dietary protein content had no 
KNOWLTON ET AL.

Table 3. The effects of treatment (T), collection day (CD), and their interaction on DM and N utilization

\begin{tabular}{|c|c|c|c|c|c|c|}
\hline \multirow[b]{2}{*}{ Item } & \multicolumn{2}{|c|}{$\operatorname{Diet}^{1}$} & \multirow[b]{2}{*}{ SEM } & \multicolumn{3}{|c|}{$P<$} \\
\hline & $\mathrm{HP}$ & LP & & $\mathrm{T}$ & $\mathrm{CD}$ & $\mathrm{T} \times \mathrm{CD}$ \\
\hline DMI, $\mathrm{kg} / \mathrm{d}$ & 11.1 & 10.7 & 0.32 & 0.40 & 0.01 & 0.01 \\
\hline DM digestibility, $\%$ & 67.4 & 66.8 & 0.87 & 0.61 & 0.01 & 0.01 \\
\hline $\mathrm{N}$ intake, $\mathrm{g} / \mathrm{d}$ & 228.9 & 149.0 & 5.59 & 0.01 & 0.01 & 0.04 \\
\hline Urine volume, $\mathrm{L} / \mathrm{d}$ & 11.2 & 9.0 & 1.99 & 0.01 & 0.05 & 0.01 \\
\hline Urinary $\mathrm{N}, \mathrm{g} / \mathrm{d}$ & 110.0 & 52.9 & 4.95 & 0.01 & 0.01 & 0.07 \\
\hline Urinary urea $\mathrm{N}, \mathrm{g} / \mathrm{d}$ & 89.3 & 29.6 & 4.01 & 0.01 & 0.04 & 0.54 \\
\hline Fecal N, g/d & 69.2 & 70.5 & 3.20 & 0.79 & 0.01 & 0.01 \\
\hline Apparent N digestibility, $\%$ & 69.6 & 52.6 & 1.41 & 0.01 & 0.01 & 0.02 \\
\hline $\mathrm{N}$ balance, $\mathrm{g} / \mathrm{d}$ & 49.5 & 25.5 & 4.85 & 0.01 & 0.01 & 0.28 \\
\hline
\end{tabular}

significant effects on DMI and DM digestibility, as has been observed by others feeding diets similar to these (Gabler and Heinrichs, 2003; Cole et al., 2005; Groff and $\mathrm{Wu}, 2005)$. Urine volume was greater in heifers fed the HP diet, likely because greater urine volume was required to excrete the excess N (Sannes et al., 2002). Nitrogen intake, urinary $N$, and urinary urea $N$ excretion were higher with the HP diet, and fecal $\mathrm{N}$ was not affected by dietary protein content. The increase in excretion of urinary $\mathrm{N}$ and constant fecal $\mathrm{N}$ excretion in response to increased dietary protein content have been reported previously (Marini and Van Amburgh, 2003; Marini et al., 2004). Nitrogen digestibility and $\mathrm{N}$ balance were higher in heifers fed the HP diet compared with those fed the LP diet. Increased apparent N digestibility with increasing dietary protein content is likely attributable to dilution of metabolic fecal N.

\section{Collection Method and Urinary N Retention}

Collection method had no significant effect on concentration or excretion of urinary total $\mathrm{N}$ or urea $\mathrm{N}$ (Table 4), and there was no interaction of diet with collection method. Both the acid-before and acid-after methods have been used to preserve urinary $\mathrm{N}$, with acids used including boric acid, hydrochloric acid, phosphoric acid, and sulfuric acid (e.g., Burge et al., 1993;
Wilkerson et al., 1997; Hoffman et al., 2001; Sevi et al., 2006). Often, acidified urine samples are frozen at $-20^{\circ} \mathrm{C}$ before analysis to provide additional control of N loss (e.g., Gehman et al., 2008; Khan et al., 2008). In the current study, the ice, acid-before, and acid-after methods yielded similar urinary $\mathrm{N}$ concentrations. The ice collection method avoids the hazard of acid use and would be especially appropriate for studies in which subsequent ammonia volatilization from urine is the explicit focus.

\section{Collection Day and Duration of Collection Period}

Interaction of Diet with Day. There was a significant interaction of diet and day for fecal $\mathrm{N}$, and a trend for the same for urinary $\mathrm{N}(P<0.07)$. The magnitude of the interaction on urinary $\mathrm{N}$ was small, with response to diet diverging on $\mathrm{d} 2$ and 3 (Figure 1). Day slices for urinary $\mathrm{N}$ confirmed that the effect of diet was highly significant on each day of collection. In contrast, fecal $\mathrm{N}$, which was much more variable than urinary $\mathrm{N}$, was not affected by the main effect of diet, and the interaction of diet and day was obvious on $\mathrm{d} 3$ (Figure 2a). Fecal N excretion was similar in heifers fed HP and LP diets on d 1, 2, 4, and 5, but slice analyses indicated that heifers fed the LP diet excreted more fecal $\mathrm{N}$ on $\mathrm{d} 3$ than did heifers fed the HP diet. A bio-

Table 4. The effects of collection method (CM) on urinary N concentration and total excretion

\begin{tabular}{|c|c|c|c|c|c|c|}
\hline \multirow[b]{2}{*}{ Item } & \multicolumn{3}{|c|}{$\mathrm{CM}^{1}$} & \multirow[b]{2}{*}{ SEM } & \multicolumn{2}{|c|}{$P$-value ${ }^{2}$} \\
\hline & Acid-before & Acid-after & Ice & & $\mathrm{CM}$ & $\mathrm{CM} \times \mathrm{T}$ \\
\hline Urinary $\mathrm{N}$ concentration, $\mathrm{g} / \mathrm{L}$ & 9.18 & 9.25 & 9.20 & 0.94 & 0.97 & 0.67 \\
\hline Urinary $\mathrm{N}$ excretion, $\mathrm{g} / \mathrm{d}$ & 81.3 & 81.4 & 82.0 & 3.77 & 0.96 & 0.57 \\
\hline Urinary urea $\mathrm{N}$ concentration, $\mathrm{g} / \mathrm{L}$ & 6.53 & 6.37 & 6.85 & 0.93 & 0.36 & 0.64 \\
\hline Urinary urea $\mathrm{N}$ excretion, $\mathrm{g} / \mathrm{d}$ & 58.7 & 57.7 & 62.1 & 3.78 & 0.31 & 0.79 \\
\hline
\end{tabular}

${ }^{1}$ Acid-before $=$ collection containers acidified before collection; acid-after $=$ collection container acidified after $6 \mathrm{~h}$ of collection; ice $=$ collection container chilled.

${ }^{2}$ The 3 -way interaction $\mathrm{CM} \times$ treatment $(\mathrm{T}) \times$ collection day was not significant. 


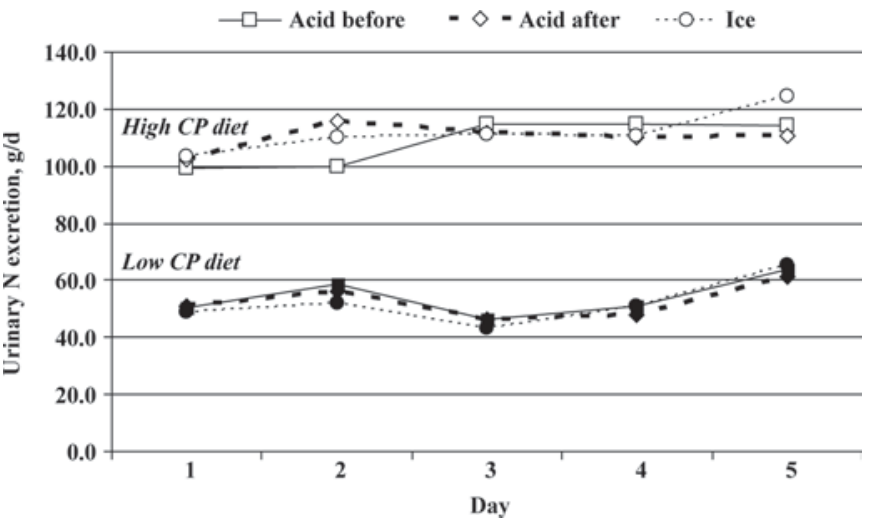

Figure 1. Effect of dietary treatment (high $\mathrm{CP}=$ open symbols; low $\mathrm{CP}=$ closed symbols) and collection method (acidified before collection, acidified after 6 -h collection, or stored on ice) on urinary $\mathrm{N}$ excretion by day. (Treatment $\mathrm{SEM}=4.95, P<0.01$; day $\mathrm{SEM}=4.01$, $P<0.01$; diet $\times$ day $\mathrm{SEM}=5.68, P<0.06$; collection method SEM $=3.77, P<0.96$; diet $\times$ collection method $\mathrm{SEM}=5.33, P<0.57$; diet $\times$ day $\times$ collection method SEM $=7.17, P<0.88$.)

logical explanation for this interaction is not obvious. There was no effect of the interaction of diet and day on $\mathrm{N}$ balance (Figure 2b).

Effect of Collection Day and Duration of the Collection Period. Intake and digestibility of DM and $\mathrm{N}$ declined in a linear fashion during the collection week (Table 5). The decline in feed intake and digestibility implies increasing discomfort associated with confinement to the collection stalls. However, these heifers were accustomed to being handled and the metabolism stalls were large, measuring $1.22 \mathrm{~m}$ in width by $1.98 \mathrm{~m}$ in length, with rubber-filled mattresses as a surface. Despite these precautions, intake and digestibility declined, particularly on d 5 .

Collection day also affected urinary, fecal, and total $\mathrm{N}$ excretion (Table 5; Figures 1 and 2a), with excretion of all of these increasing linearly across the collection week (fecal $\mathrm{N}$ increased linearly and quadratically). Increases
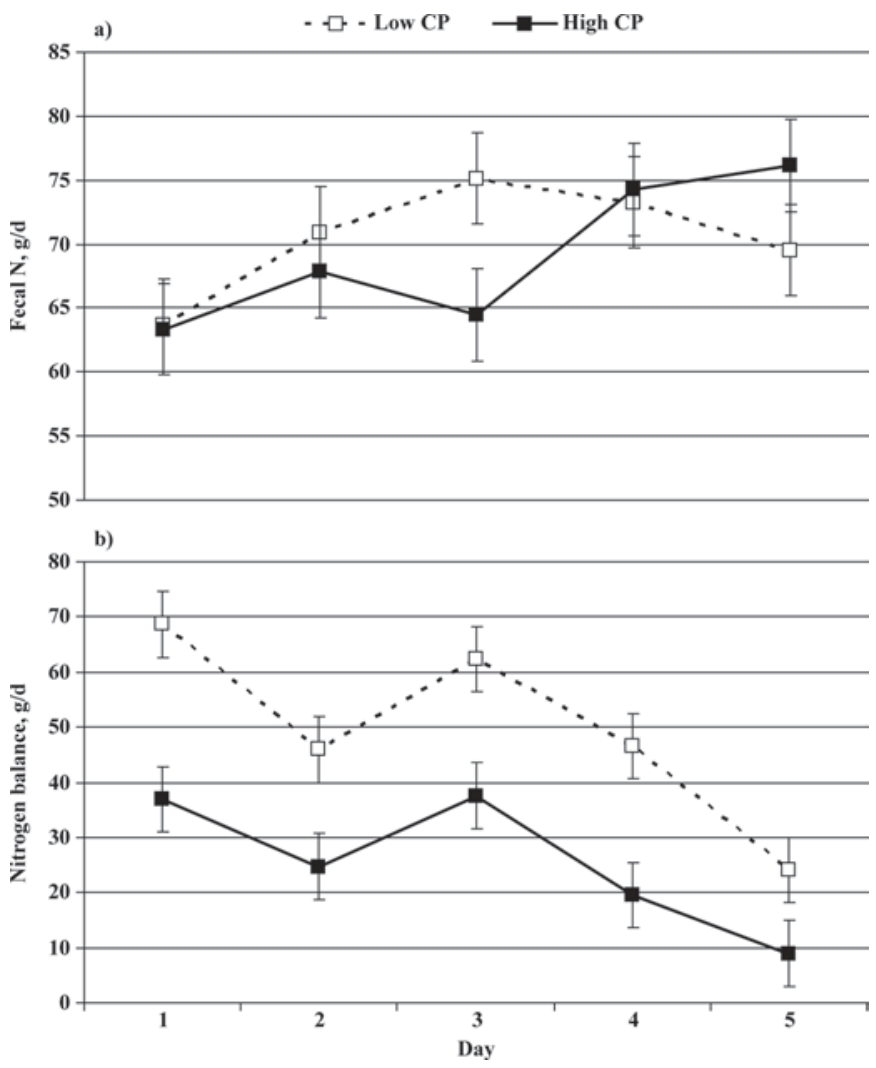

Figure 2. Effect of dietary treatment (high $\mathrm{CP}$ or low $\mathrm{CP}$ ) on a) fecal $\mathrm{N}$ excretion and b) $\mathrm{N}$ balance by day. (Fecal $\mathrm{N}$ : treatment SEM $=3.20, P<0.74$; day $\mathrm{SEM}=2.81, P<0.01$; diet $\times$ day $\mathrm{SEM}=3.60$, $P<0.01$. N balance: treatment $\mathrm{SEM}=4.85, P<0.01$; day $\mathrm{SEM}=$ 4.97, $P<0.01$; diet $\times$ day SEM 5.94, $P<0.27$.)

in urinary $\mathrm{N}$ were caused by linear increases in urine weight and urinary and fecal $\mathrm{N}$ concentration (data not shown). Because of the combination of reduced intake, reduced digestibility, and increased urinary excretion, $\mathrm{N}$ balance declined linearly across the collection week.

Significant effects of day implied that one or more days deviated from the mean or that some pattern

Table 5. The effects of collection day (CD) on DM and $\mathrm{N}$ digestion and excretion

\begin{tabular}{|c|c|c|c|c|c|c|c|c|c|}
\hline \multirow[b]{2}{*}{ Item } & \multicolumn{5}{|c|}{$\mathrm{CD}$} & \multirow[b]{2}{*}{ SEM } & \multicolumn{3}{|c|}{$P$-value ${ }^{1}$} \\
\hline & 1 & 2 & 3 & 4 & 5 & & $\mathrm{CD}$ & $\mathrm{L}$ & Q \\
\hline DMI, kg/d & 11.1 & 10.9 & 11.5 & 10.8 & 10.4 & 0.32 & 0.01 & 0.01 & 0.01 \\
\hline DM digestibility, $\%$ & 70.4 & 66.8 & 68.6 & 66.1 & 63.1 & 0.78 & 0.01 & 0.01 & 0.23 \\
\hline $\mathrm{N}$ intake, $\mathrm{g} / \mathrm{d}$ & 192 & 187 & 199 & 188 & 179 & 5.58 & 0.01 & 0.01 & 0.03 \\
\hline Fecal N, g/d & 63 & 69 & 70 & 74 & 73 & 2.58 & 0.01 & 0.01 & 0.04 \\
\hline Apparent N digestibility, \% & 65.3 & 61.3 & 62.5 & 58.7 & 57.8 & 1.23 & 0.01 & 0.01 & 0.27 \\
\hline Urine volume, $\mathrm{L} / \mathrm{d}$ & 9.24 & 10.3 & 9.97 & 10.5 & 10.4 & 2.00 & 0.05 & & \\
\hline Urinary $\mathrm{N}, \mathrm{g} / \mathrm{d}$ & 76 & 82 & 79 & 81 & 90 & 4.01 & 0.01 & 0.01 & 0.25 \\
\hline Urinary urea $\mathrm{N}, \mathrm{g} / \mathrm{d}^{2}$ & 56 & 58 & 57 & 58 & 67 & 4.17 & 0.04 & 0.02 & 0.16 \\
\hline Total N excretion, g/d & 140 & 151 & 149 & 155 & 163 & 5.88 & 0.01 & 0.01 & 0.85 \\
\hline
\end{tabular}

${ }^{1} \mathrm{~L}=$ linear effect; $\mathrm{Q}=$ quadratic effect.

${ }^{2}$ Urinary urea $\mathrm{N}$ determined as urea $\mathrm{N}+\mathrm{NH}_{3}-\mathrm{N}$. 
Table 6. The effects of the length of collection on variability in urinary $N(g / d)^{1}$

\begin{tabular}{|c|c|c|c|c|c|c|c|c|c|}
\hline \multirow[b]{2}{*}{ CD included } & \multicolumn{3}{|c|}{ SEM } & \multicolumn{6}{|c|}{$P$-value } \\
\hline & $\mathrm{T}$ & $\mathrm{CD}$ & $\mathrm{CM}$ & $\mathrm{T}$ & $\mathrm{CD}$ & $\mathrm{CM}$ & $\mathrm{T} \times \mathrm{CD}$ & $\mathrm{T} \times \mathrm{CM}$ & $\mathrm{T} \times \mathrm{CD} \times \mathrm{CM}$ \\
\hline 1 to 5 & 4.95 & 4.01 & 3.77 & 0.01 & 0.01 & 0.95 & 0.07 & 0.57 & 0.90 \\
\hline 1 to 4 & 4.82 & 3.71 & 3.61 & 0.01 & 0.09 & 0.78 & 0.01 & 0.52 & 0.66 \\
\hline 1 to 3 & 5.10 & 3.87 & 3.87 & 0.01 & 0.07 & 0.52 & 0.01 & 0.31 & 0.62 \\
\hline 2 to 5 & 4.91 & 3.97 & 3.81 & 0.01 & 0.01 & 0.95 & 0.08 & 0.64 & 0.70 \\
\hline 2 to 4 & 4.57 & 3.48 & 3.48 & 0.01 & 0.39 & 0.72 & 0.02 & 0.55 & 0.27 \\
\hline
\end{tabular}

${ }^{1} \mathrm{CD}=$ collection day; $\mathrm{T}=$ treatment $\mathrm{CM}=$ collection method.

was present in the data. Multiple explanations are possible. If adaptation to the stall or to the catheter was inadequate, the first day's data would be suspect. Increasing the duration of catheterization increases the risk of urinary tract infections, which is more likely to affect latter days in the period (Warren, 2001; Bubenik et al., 2007). However, body temperatures were normal throughout the study and no animals exhibited symptoms of illness during or after collection weeks. Although no negative reaction to the urinary catheters was directly observed, results may have differed if heifers were not catheterized. Similarly, stall comfort would be more likely to affect performance in the latter portion of the collection period, although stall size and design would seem to obviate this concern.

In this study, the later days of the collection period appeared to be more of a concern than the earlier days. To assess this, various days were eliminated from the analysis and the effect of treatment, storage, and day with the resulting collection period were assessed. Collection periods evaluated included d 1 through 5 , d 1 through 4, d 1 through 3, d 2 through 5, and d 2 through 4 (Table 6).

For urinary $\mathrm{N}$, the largest reduction in variability came with eliminating the data from $\mathrm{d} 5$. Urinary $\mathrm{N}$ excretion on that day was notably higher than in $\mathrm{d} 1$ to 4. A further reduction in variability in urinary $\mathrm{N}$ excretion was achieved with the elimination of $\mathrm{d} 1$ data, suggesting that a longer precollection adaptation to the stall and catheter was desirable. Additional work is needed to determine whether the effect of day is caused by factors biasing the results on the first and last day of the collection or whether this variation is random "noise."

Fecal $\mathrm{N}$ was much more variable than urinary N (Figure 2), but changing the number of collection days used to analyze fecal $\mathrm{N}$ data did not alter the significance of treatment, collection day, and their interaction (Table 7 ). Using data from only d 1, 2, and 3 yielded the lowest SEM for treatment and day, but the change in SEM for any combination of days was not noticeably different. Firm conclusions about optimum duration of total collection of feces and urine cannot be drawn from this data set. One possibility worth exploring is whether variability in urinary $\mathrm{N}$ continues to increase with increased duration of collection. If so, the most accurate measures of urinary $\mathrm{N}$ may call for a shorter collection period than is needed for measurement of fecal N.

\section{CONCLUSIONS}

Urinary $\mathrm{N}$ preservation was similar for urine acidified at the start of collection, acidified after $6 \mathrm{~h}$ of collection, or chilled immediately, regardless of dietary protein content. No interaction was observed between dietary protein and urine preservation method, so any of these 3 collection methods is appropriate and the chilled immediately approach may be useful for studies focused on ammonia emission. Urinary $\mathrm{N}$ excretion was more consistent among days than was fecal $\mathrm{N}$ excretion, with increasing duration of collection increasing variability of both measures. Additional work is needed to more fully evaluate optimum duration of collection of feces and urine for $\mathrm{N}$ balance measurements.

\section{ACKNOWLEDGMENTS}

The authors acknowledge the careful animal care and analytical support of Virginia Tech Dairy Science students Shane Martin, Emma Pemberton, and Megan Taylor, and the Virginia Tech Dairy Center

Table 7. The effects of the length of collection on variability in fecal $\mathrm{N}(\mathrm{g} / \mathrm{d})^{1}$

\begin{tabular}{lcccccc}
\hline & \multicolumn{2}{c}{ SEM } & & \multicolumn{3}{c}{$P$-value } \\
\cline { 2 - 3 } \cline { 5 - 6 } CD included & $\mathrm{T}$ & $\mathrm{CD}$ & & $\mathrm{T}$ & $\mathrm{CD}$ & $\mathrm{T} \times \mathrm{CD}$ \\
\hline 1 to 5 & 3.20 & 2.54 & & 0.79 & 0.01 & 0.01 \\
1 to 4 & 3.06 & 2.46 & & 0.47 & 0.01 & 0.03 \\
1 to 3 & 2.40 & 1.88 & & 0.20 & 0.01 & 0.01 \\
2 to 5 & 3.77 & 2.87 & & 0.78 & 0.04 & 0.01 \\
2 to 4 & 3.77 & 2.86 & & 0.45 & 0.05 & 0.02 \\
\hline
\end{tabular}

${ }^{1} \mathrm{CD}=$ collection day; $\mathrm{T}=$ treatment. 
farm staff, especially Shane Brannock, Curtis Caldwell, and William Saville. The authors acknowledge general departmental funding provided by the Virginia State Dairymen's Association (Bridgewater).

\section{REFERENCES}

AOAC. 1984. Official Methods of Analysis. 14th ed. Assoc. Off. Anal. Chem., Arlington, VA.

Biertuempfel, P. H., G. V. Ling, and G. A. Ling. 1981. Urinary tract infection resulting from catheterization in healthy adult dogs. J. Am. Vet. Med. Assoc. 178:989-991.

Bubenik, L. J., G. L. Hosgood, D. R. Waldron, and L. A. Snow. 2007. Frequency of urinary tract infection in catheterized dogs and comparison of bacterial culture and susceptibility testing results for catheterized and noncatheterized dogs with urinary tract infection. J. Am. Vet. Med. Assoc. 231:893-899.

Burge, J. C., P. Choban, T. McKnight, M. K. Kyler, and L. Flancbaum. 1993. Urinary ammonia plus urinary urea nitrogen as an estimate of total urinary nitrogen in patients receiving parenteral nutrition support. J. Parenter. Enteral Nutr. 17:529-531.

Cochrane, D. C. 1915. The determination of ammonia nitrogen in steer's urine. J. Biol. Chem. 23:311-316.

Cole, N. A., R. N. Clark, R. W. Todd, C. R. Richardson, A. Gueye, L. W. Greene, and K. McBride. 2005. Influence of dietary crude protein concentration and source on potential ammonia emissions from beef cattle manure. J. Anim. Sci. 83:722-731.

Ferraz, R. R., A. C. Baxmann, L. G. Ferreira, J. L. Nishiura, P. R. Siliano, S. A. Gomes, S. R. Moreira, and I. P. Heilberg. 2006. Preservation of urine samples for metabolic evaluation of stoneforming patients. Urol. Res. 34:329-337.

Gabler, M. T., and A. J. Heinrichs. 2003. Effects of increasing dietary protein on nutrient utilization in heifers. J. Dairy Sci. 86:21702177.

Gehman, A. M., P. J. Kononoff, C. R. Mullins, and B. N. Janicek. 2008. Evaluation of nitrogen utilization and the effects of monensin in dairy cows fed brown midrib corn silage. J. Dairy Sci. 91:288300.

Gillespie, T., J. Fewster, and R. G. Masterton. 1999. The effect of specimen processing delay on borate urine preservation. J. Clin. Pathol. 522:95-98.

Groff, E. B., and Z. Wu. 2005. Milk production and nitrogen excretion of dairy cows fed different amounts of protein and varying proportions of alfalfa and corn silage. J. Dairy Sci. 88:36193632.

Hoffman, P. C., N. M. Esser, L. M. Bauman, S. L. Denzine, M. Engstrom, and H. Chester-Jones. 2001. Short communication: Effect of dietary protein on growth and nitrogen balance of Holstein heifers. J. Dairy Sci. 84:843-847.

Kaplan, A. 1965. Urea nitrogen and urinary ammonia. Pages 245-256 in Standard Methods of Clinical Chemistry. Vol. 5. S. Meites, ed. Academic Press, New York, NY.
Khan, M. A., H. J. Lee, W. S. Lee, H. S. Kim, S. B. Kim, S. B. Park, K. S. Baek, J. K. Ha, and Y. J. Choi. 2008. Starch source evaluation in calf starter: II. Ruminal parameters, rumen development, nutrient digestibilities, and nitrogen utilization in Holstein calves. J. Dairy Sci. 91:1140-1149.

López, S., E. Llamazares, and J. S. Gonzalez. 1998. Determination of ammonia nitrogen in the urine of small ruminants. J. Sci. Food Agric. 781:95-101.

Marini, J. C., and M. E. Van Amburgh. 2005. Partition of nitrogen excretion in urine and the feces of Holstein replacement heifers. J. Dairy Sci. 88:1778-1784.

Marini, J. C., J. D. Klein, J. M. Sands, and M. E. Van Amburgh. 2004. Effects of nitrogen intake on nitrogen recycling and urea transporter abundance in lambs. J. Anim. Sci. 82:1157-1164.

Marini, J. C., and M. E. Van Amburgh. 2003. Nitrogen metabolism and recycling in Holstein heifers. J. Anim. Sci. 81:545-552.

Misselbrook, T. H., J. M. Powell, G. A. Broderick, and J. H. Grabber. 2005. Dietary manipulation in dairy cattle: Laboratory experiments to assess the influence on ammonia emissions. J. Dairy Sci. 88:1765-1777.

NRC. 2001. Nutrient Requirements of Dairy Cattle. 7th rev. ed. Natl. Acad. Sci., Washington, DC.

NRC. 2003. Air Emissions from Animal Feeding Operations: Current Knowledge, Future Needs. Natl. Acad. Sci., Washington, DC.

Porter, I. A., and J. Brodie. 1969. Boric acid preservation of urine samples. BMJ 2:353-355.

Reynal, S. M., and G. A. Broderick. 2005. Effect of dietary level of rumen-degraded protein on production and nitrogen metabolism in lactating dairy cows. J. Dairy Sci. 88:4045-4064.

Sannes, R. A., M. A. Messman, and D. B. Vagnoni. 2002. Form of rumen-degradable carbohydrate and nitrogen on microbial protein synthesis and protein efficiency of dairy cows. J. Dairy Sci. 85:900-908.

SAS Institute. 2004. SAS User's Guide: Statistics. Version 9.1.2. SAS Institute, Inc., Cary, NC.

Sato, H., and J. Nakajima. 2005. Fecal ammonia, urea, volatile fatty acid and lactate levels in dairy cows and their pathophysiological significance during diarrhea. Anim. Sci. J. 76:595-599.

Sevi, A., M. Albenzio, G. Annicchiarico, M. Caroprese, R. Marino, and A. Santillo. 2006. Effects of dietary protein level on ewe milk yield and nitrogen utilization, and on air quality under different ventilation rates. J. Dairy Res. 73:197-206.

Van Soest, P. J., J. B. Robertson, and B. A. Lewis. 1991. Methods for dietary fiber, neutral detergent fiber, and nonstarch polysaccharides in relation to animal nutrition. J. Dairy Sci. 74:3583-3597.

Warren, J. W. 2001. Catheter-associated urinary tract infections. Int. J. Antimicrob. Agents 17:299-303.

Watson, P. G., and B. I. Duerden. 1977. Laboratory assessment of physical and chemical methods of preserving urine specimens. J. Clin. Pathol. 30:532-536.

Wilkerson, V. A., B. P. Glenn, and K. R. McLeod. 1997. Energy and nitrogen balance in lactating cows containing dry or high moisture corn in either rolled or ground form. J. Dairy Sci. 80:2487-2496. 